\title{
Potential of Macrostomum lignano to recover from $\gamma$-ray irradiation
}

\author{
Katrien De Mulder • Georg Kuales • Daniela Pfister • \\ Bernhard Egger • Thomas Seppi • Paul Eichberger • \\ Gaetan Borgonie • Peter Ladurner
}

Received: 14 July 2009 /Accepted: 10 December 2009/Published online: 2 February 2010

(C) The Author(s) 2010. This article is published with open access at Springerlink.com

\begin{abstract}
Stem cells are the only proliferating cells in flatworms and can be eliminated by irradiation with no damage to differentiated cells. We investigated the effect of fractionated irradiation schemes on Macrostomum lignano, namely, on survival, gene expression, morphology and regeneration. Proliferating cells were almost undetectable during the first week post-treatment. Cell proliferation and gene expression were restored within 1 month in a dosedependent manner following exposure to up to $150 \mathrm{~Gy}$
\end{abstract}

This work was supported by a predoctoral FWO grant to K.D.M (Belgium) and FWF grant no. 18099 to P.L (Austria).

Electronic supplementary material The online version of this article (doi:10.1007/s00441-009-0915-6) contains supplementary material, which is available to authorized users.

K. De Mulder $\cdot$ G. Kuales $\cdot$ D. Pfister $\cdot$ B. Egger $\cdot$ P. Ladurner $(\bowtie)$ Institute of Zoology and Center for Molecular Biosciences, University of Innsbruck,

Technikerstrasse 25,

6020 Innsbruck, Austria

e-mail: peter.ladurner@uibk.ac.at

K. De Mulder $\cdot$ G. Borgonie

Department of Biology, University of Ghent,

Ledeganckstraat 35,

9000 Ghent, Belgium

T. Seppi $\cdot$ P. Eichberger

Department of Radiotherapy and Radiation Oncology, Innsbruck Medical University Hospital,

Innsbruck Medical University,

Anichstrasse 35,

6020 Innsbruck, Austria

Present Address:

K. De Mulder

Hubrecht Institute,

Uppsalalaan 8,

3584 CT Utrecht, The Netherlands irradiation. During recovery, stem cells did not cross the midline but were restricted within lateral compartments. An accumulated dose of 210 Gy resulted in a lethal phenotype. Our findings demonstrate that $M$. lignano represents a suitable model system for elucidating the effect of irradiation on the stem cell system in flatworms and for improving our understanding of the recovery potential of severely damaged stem-cell systems.

Keywords Irradiation · Stem cells · Planaria · Flatworm · Macrostomum lignano (Platyhelminthes)

\section{Introduction}

Stem cells are defined as undifferentiated cells that possess the unique capacity to produce offspring that differentiate into various cell types while retaining their potential for self-renewal (Morrison and Spradling 2008). The number of stem cells and their proliferation activity and decision to differentiate must be tightly controlled during development and homeostasis to avoid tumour formation or premature ageing. However, stem cells in higher organisms are difficult to study in vivo and are not always accessible for experimental analysis. Since the simulation of the natural stem cell environment is complex in vitro, the use of model organisms in which fundamental aspects of stem cell biology can be addressed in vivo has become highly attractive (Bosch 2008; Tanaka 2003; Tsai et al. 2002; Newmark and Sanchez 2002; Weissman 2000).

With the introduction of functional genomics, flatworms have been proposed as model organisms for elucidating the underlying molecular basis of stem cell biology (Sanchez 2004). Members of the phylum Platyhelminthes are well known for their high regeneration capacity based upon 
totipotent stem cells (Rossi et al. 2008; Handberg-Thorsager et al. 2008; Egger et al. 2007; Sanchez 2004; Reddien and Sanchez 2004; Agata 2003; Newmark and Sanchez 2002). Wolff and Dubois (1948) originally demonstrated that neoblasts could be specifically eliminated by $\gamma$-ray irradiation (in the flatworm literature, this type of irradiation is often defined as "hard X-rays"), without severely affecting differentiated cells. Since this discovery, radiation exposure has become a method widely used in flatworm stem cell research for testing and confirming various hypotheses. First, the assumed crucial function of neoblasts during postembryonic development, homeostasis, cell renewal and regeneration has been clearly demonstrated; none of these biological processes is maintained following the elimination of the stem cell system by irradiation (Salvetti et al. 2009; Kobayashi et al. 2008; Rossi et al. 2007; Baguna et al. 1989; Brondsted 1969), whereas differentiated cells are unable to perform these functions. Second, the differentiation potential of purified donor neoblasts can be conveniently analysed; lethally irradiated worms can be rescued after the injection of highly enriched stem cell populations, whereas the injection of differentiated cells does not increase the survival rate (Kobayashi et al. 2008; Baguna et al. 1989). Third, gene expression profiling of irradiated flatworms has confirmed stem-cell-specific gene expression in triclads (so called planarians; Eisenhoffer et al. 2008; Rossi et al. 2006; Guo et al. 2006; Orii et al. 2005; Salvetti et al. 2005; Reddien et al. 2005; Cebria et al. 2002). Lastly, in order to identify novel candidate stem cell genes, subtraction libraries have been generated from irradiated versus non-irradiated worms and shown an enrichment of stem-cell-specific genes in the library (Eisenhoffer et al. 2008; Rossi et al. 2007).

The radiation sensitivity of flatworms largely depends on the species (Lange 1968). For Dugesia ryukyuensis, doses of 4.4-8.8 Gray (Gy) have been determined to be the lethal dose range (Kobayashi et al. 2008). For Dugesia japonica, on the other hand, a total dose of $30 \mathrm{~Gy}$ has proved to be necessary to obtain lethality (Salvetti et al. 2002, 2005, 2009; Rossi et al. 2006; Orii et al. 1999). In contrast, a univocal standard radiation exposure is not described for Schmidtea mediterranea and doses ranging from 40-100 Gray have been used (Palakodeti et al. 2008; Eisenhoffer et al. 2008; Guo et al. 2006; Reddien et al. 2005). Our research focuses on the stem cell system of the flatworm Macrostomum lignano (Ladurner et al. 2005, 2008). Recent work on this species has demonstrated the advantage of $M$. lignano for studying stem cell biology and regeneration (Ladurner et al. 2000, 2008; Pfister et al. 2008; Nimeth et al. 2007; Pfister et al. 2007; Egger et al. 2006; De Mulder et al. 2009). The detailed morphological knowledge and transparency of $M$. lignano provides the opportunity to analyse the effects of various stress conditions at a morphological level. Furthermore, proliferation activity and gene function can be readily studied during biological processes by soaking the animal in diverse solutions (Pfister et al. 2007, 2008; Nimeth et al. 2002, 2004, 2007; De Mulder et al. 2009). In addition, the ease of culturing and the unlimited access to eggs throughout the whole year make M. lignano a convenient experimental model. The availability of protocols for in situ hybridization and RNA interference (Pfister et al. 2007, 2008; De Mulder et al. 2009) and current work on genome sequencing (E. Berezikov et al., personal communicaton) should further foster genomic and transcriptomic approaches with M. lignano.

In an earlier report, we have described the exceptional capacity of $M$. lignano to recover from single radiation doses of up to 200 Gy (Pfister et al. 2007). As a continuation thereof, single doses of $\gamma$-ray irradiation in this study have been modified to fractionated exposures in order to define a lethal endpoint. Several protocols with variations in dose, punctuation and time schedule have been applied and compared concerning their effect on (1) survival, (2) proliferation activity, (3) stem cell and housekeeping gene expression, (4) morphology, (5) regeneration capacity, (6) development and (7) reproduction. In addition, the manner of stem cell repopulation after irradiation in M. lignano is discussed.

\section{Materials and methods}

\section{Animal culture}

Macrostomum lignano (Platyhelminthes, Macrostomida; Ladurner et al. 2005) were cultured in Petri dishes filled with nutrient-enriched artificial seawater ( $f / 2)$. During the whole experiment, staged animals (4-6 weeks) were fed ad libitum on the diatom Nitzschia curvilineata (Andersen et al. 2005; Rieger et al. 1988).

\section{Whole-mount in situ hybridization}

Whole-mount in situ hybridization was performed according to a protocol described earlier (Pfister et al. 2007). Sense and antisense digoxigenin (DIG)-labelled RNA probes were obtained with a DIG RNA-labelling kit (Roche) following the manufacturer's protocol. DNA templates used for RNA probe synthesis were Angu 7606 for macpiwi (GenBank accession no. AM942740), clone Ml_aW_011_J16 for macactin (GenBank accession no. FN263188) and Angu 4194 for macboule (http:// flatworm.uibk.ac.at/macest/blast.php). Detailed information of the macboule sequence will be published separately. Riboprobes were used at a final concentration of $0.025 \mathrm{ng} / \mu \mathrm{l}$ for macpiwi and macboule and $0.05 \mathrm{ng} / \mu \mathrm{l}$ for macactin. 
BrdU and anti-phospho-histone H3 double-labelling

To label neoblasts in S-phase at $1 \mathrm{~h}, 1$ day, 1 week, 2 weeks and 3 weeks post-irradiation, animals were soaked for $30 \mathrm{~min}$ in culture medium containing $5 \mathrm{mM}$ bromodeoxyuridine (BrdU; Sigma). Depending on the experiment, specimens were rinsed several times in artificial seawater and fixed directly ("pulse experiment") or $72 \mathrm{~h}$ later ("pulse-chase experiment"), the latter being a time period in which cells were able to divide, migrate and differentiate. After fixation, BrdU/H3 staining was performed as described elsewhere (Ladurner et al. 2000) except for protease XIV treatment, which was performed at a final concentration of $0.1 \mathrm{mg} / \mathrm{ml}$ for $20 \mathrm{~min}$ at $37^{\circ} \mathrm{C}$.

Irradiation by $\gamma$-rays

For all experiments, worms were exposed to $\gamma$-rays of $6 \mathrm{MV}$ at $400 \mathrm{cGy} / \mathrm{min}$. Radiation treatment was performed with an ELEKTA Synergy Linear Accelerator (serial number: 131431, ELEKTA Oncology Systems) at the Department of Therapeutic Radiology and Oncology, Innsbruck Medical University. Dose calibration of the specific linear accelerator and the dosimetric procedure was checked in an external dosimetric audit (EQUAL-ESTRO) and indicated that the main dosimetric parameters employed in the radiotherapeutic treatments were situated within the optimal range at the time of audit. This dosimetric evaluation was valid during the experiment.

For the radiation treatment of worms an experimental setup was chosen that guaranteed broadly homogeneous dose delivery. Thirty-two tubes with worms in $3 \mathrm{ml}$ culture medium were placed in four round Perspex "phantoms" (see Electronic Supplementary Material, Fig. S7) located on the patient treatment couch. The amount of phantom material above, below and surrounding the tubes was chosen to ensure sufficient scattering conditions and to position the worms optimally for the maximum dose of the specific $\gamma$-ray energy of $6 \mathrm{MV}$. A source-surface distance (SSD) of $100 \mathrm{~cm}$ was chosen to ensure a field "s" for irradiation. With this setup, worms were irradiated with single energy doses of 15 Gy or 30 Gy up to a total dose of 210 Gy. Control worms were handled in the same way as treated worms, except that the irradiation step was omitted. An overview of the irradiation protocols used is shown in Table 1.

The first batch of animals $(n=500)$, further described as Protocol 1 (P1), was irradiated following a fractionated time schedule spread over 2 days, with a final $\gamma$-ray dose ranging from 30 to $90 \mathrm{~Gy}$ : day 1 with 30 Gy at 8.00 (protocol P1a) plus 15 Gy at 12.00 (protocol P1b) plus 15 Gy at 16.00 (protocol P1c) and the following day 2 with an additional 15 Gy at 8.00 (protocol P1d) plus 15 Gy at 16.00 (protocol P1e).

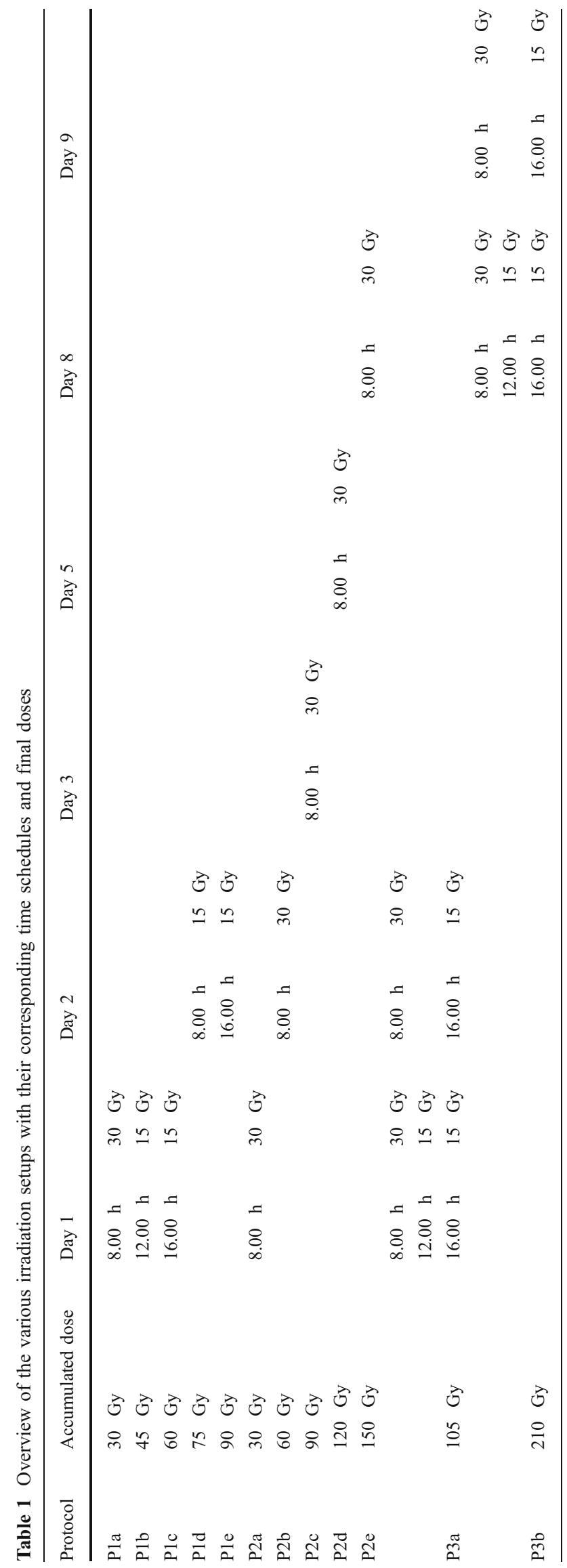


A second batch of worms $(n=500)$, further described as Protocol 2 (P2), was exposed to 30 Gy on days 1, 2, 3, 5 and 8 . These doses accumulated to 30 Gy (protocol P2a), 60 Gy (protocol P2b), 90 Gy (protocol P2c), 120 Gy (protocol P2d) and 150 Gy (protocol P2e).

A third batch of worms $(n=500)$, further described as Protocol 3 (P3), was irradiated with the following punctuated time schedule to a final dose of 105-210 Gy: day 1 with 30 Gy at $8.00,15$ Gy at 12.00 and 15 Gy at 16.00 and day 2 with 30 Gy at 8.00 and 15 Gy at 16.00 . These doses accumulated to 105 Gy (protocol P3a). This irradiation schedule was repeated 1 week later: day 8 with $30 \mathrm{~Gy}$ at $8.00,15$ Gy at 12.00 and 15 Gy at 16.00 and day 9 with 30 Gy at 8.00 and 15 Gy at 16.00 . These doses accumulated to a total of $210 \mathrm{~Gy}$ (protocol P3b). Since this radiation protocol was found to result in $100 \%$ lethality, five replicas were performed $(n=5 \times 50)$ for analysis of the survival curve.

For each batch of animals, 20 individuals were BrdU-pulsed and fixed at $1 \mathrm{~h}, 1$ day, 1 week, 2 weeks and 3 weeks postirradiation (i.e. after the last radiation exposure). Specimens were examined for gene expression (piwi, boule, actin) and Sphase $(\mathrm{BrdU}) /$ mitosis (phospho-H3) distribution.

Influence of $\gamma$-rays on postembryonic development and regeneration

Regeneration capacity and postembryonic development were analysed for worms irradiated with 60 Gy or $210 \mathrm{~Gy}$. Worms were cut 1 day after the last radiation dose at the level of the female gonopore and allowed to regenerate. Every second day, one batch of worms was observed for blastema formation.

For analysis of the effect of radiation on postembryonic development, freshly hatched worms $(\leq 1 \mathrm{~h}$ old $)$ were collected just before irradiation. The fractionated irradiation scheme applied for hatchlings was identical to that used for adults (protocols P1c, P3b).

\section{Results}

Data concerning the effect of irradiation on animal survival for all fractionated irradiation protocols are conjointly presented. All other investigated parameters are separately described.

Effect of $\gamma$-ray irradiation on survival rate

In a first experimental setup (protocols P1a-P1e, see Table 1), fractionated irradiation at total doses of up to 90 Gy were applied within 2 days. All animals remained alive until 10 days after the last administered dose of $\gamma$-ray exposure. Subsequently, dose-dependent mortality was apparent (Fig. 1a). Between 16 and 20 days, the decline in the surviving fraction of treated animals decelerated and, finally, almost completely stopped by the end of the observation period at day 50 (Fig. 1a). In the second experimental setup (protocols P2a-P2e), total doses of up to $150 \mathrm{~Gy}$ were fractionated and administered within an 8-day period (Fig. 1b). As previously observed, during an initial period of 9 days, all animals survived. This period was followed by a phase of gradual dose-dependent mortality during the subsequent 2 weeks, until day 26 when survival rates of treated animals once again began to stabilize (Fig. 1b). Following an interim period of 12 days showing an unaltered survival fraction, all animals died by day 50 . We further applied a 9-day fractionated radiation protocol with doses accumulating to up to $210 \mathrm{~Gy}$ (Fig. 1c; protocols P3a-P3b). Again, little mortality was observed during the first 11 days after the last exposure. For the $105 \mathrm{~Gy}$ protocol, about $10 \%$ of the animals survived for 1 month without any further loss. The $210 \mathrm{~Gy}$ protocol, however, was lethal for all animals (five replicas: $n=5 \times 50$ animals; Fig. 1c).

Effect of irradiation on cell proliferation and gene expression in adult animals

First, we analysed animals irradiated with $30,45,60,75$ and 90 Gy in a fractionated time schedule over 2 days (for protocols P1a-P1e, see Table 1). At $1 \mathrm{~h}$ after the final exposure to radiation, BrdU incorporation was mainly restricted to the gonads (see Electronic Supplementary Material, Fig. $\left.\mathrm{S} \mathrm{A}_{1-6}\right)$. Likewise, macpiwi expression (Fig. $\mathrm{S}_{1 \mathrm{~B}_{1-6}}$ ) dropped below the detection level in somatic stem cells. Gonadal stem cells were more resistant to $\gamma$-ray exposure. A dose-dependent decrease in macpiwi expression was apparent in the testes. Following 75 and 90 Gy, macpiwi expression became restricted to the anterior tip of the testes. In the ovaries, expression persisted at a comparatively high level. Similarly, the expression of the meiosis-specific marker macboule declined with increasing doses of irradiation (Fig. $\mathrm{S}_{1 \mathrm{C}_{1-6}}$ ). In contrast, transcript levels of macactin mRNA remained almost unaltered (Fig. $\mathrm{S}_{1} \mathrm{D}_{1-6}$ ). By 1 day post-treatment, a similar pattern was apparent with regard to recorded cell proliferation activity (see Electronic Supple-

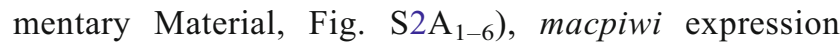
(Fig. $\mathrm{S}_{2} \mathrm{~B}_{1-6}$ ), macboule expression (Fig. $\mathrm{S}_{2} \mathrm{C}_{1-6}$ ) and the detected macactin mRNA levels (Fig. $\mathrm{S}^{2} \mathrm{D}_{1-6}$ ).

At 1 week post-irradiation (see Electronic Supplementary Material, Fig. S3) and more evidently at 2 weeks thereafter (see Electronic Supplementary Material, Fig. S4), cell proliferation and gene expression showed typical signs of recovery. By 3 weeks after initial radiation exposure, cell

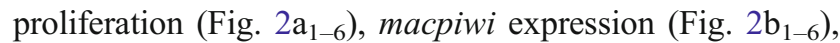
macboule expression (Fig. $2 \mathrm{c}_{1-6}$ ) and macactin mRNA 
Fig. 1 Effect of various fractionated $\gamma$-ray exposures on the survival rate of Macrostomum lignano. Survival curves following fractionated radiation setup protocols P1 (a), P2 (b) and P3 (c). For details of the protocols, see Table 1. The time schedule for $\gamma$-ray exposure is shown above each curve. Univocal lethality of protocol P3b was confirmed by T-testing P (99\%). Error bars Standard deviation

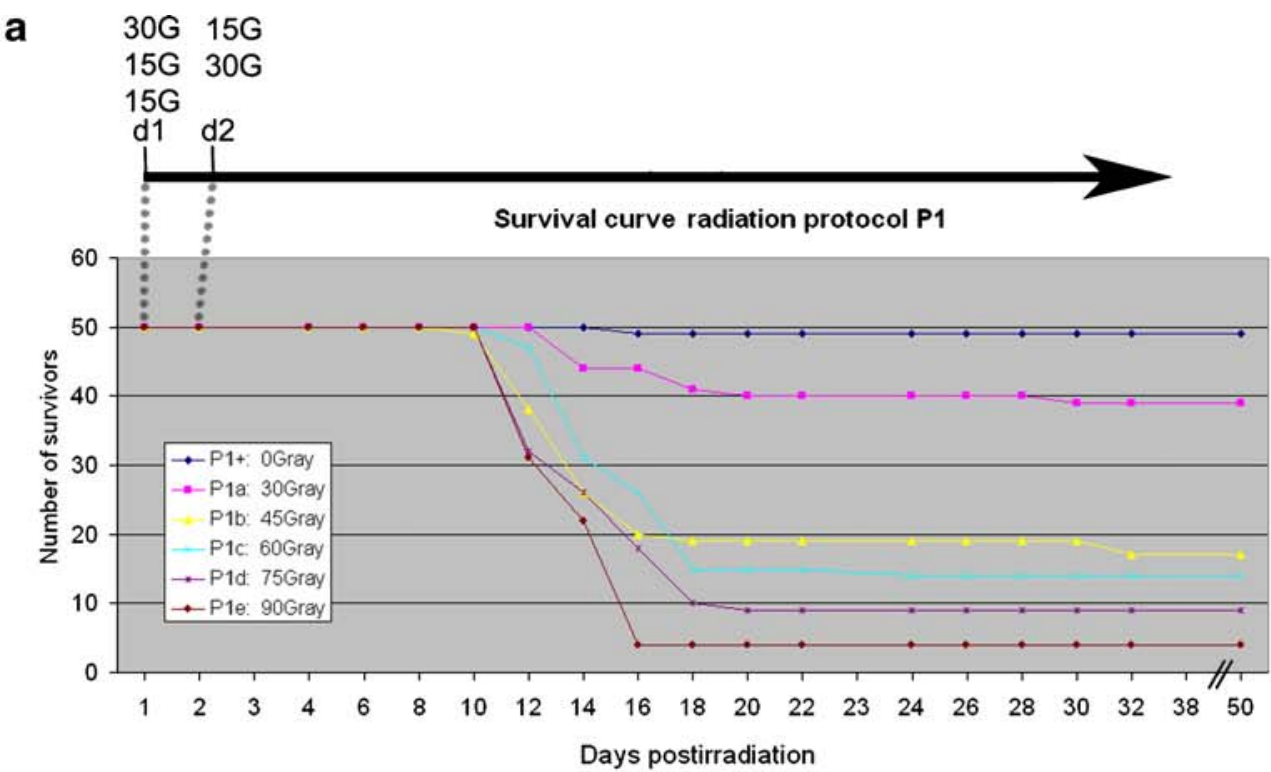

b 30G 30G 30G 30G 30G

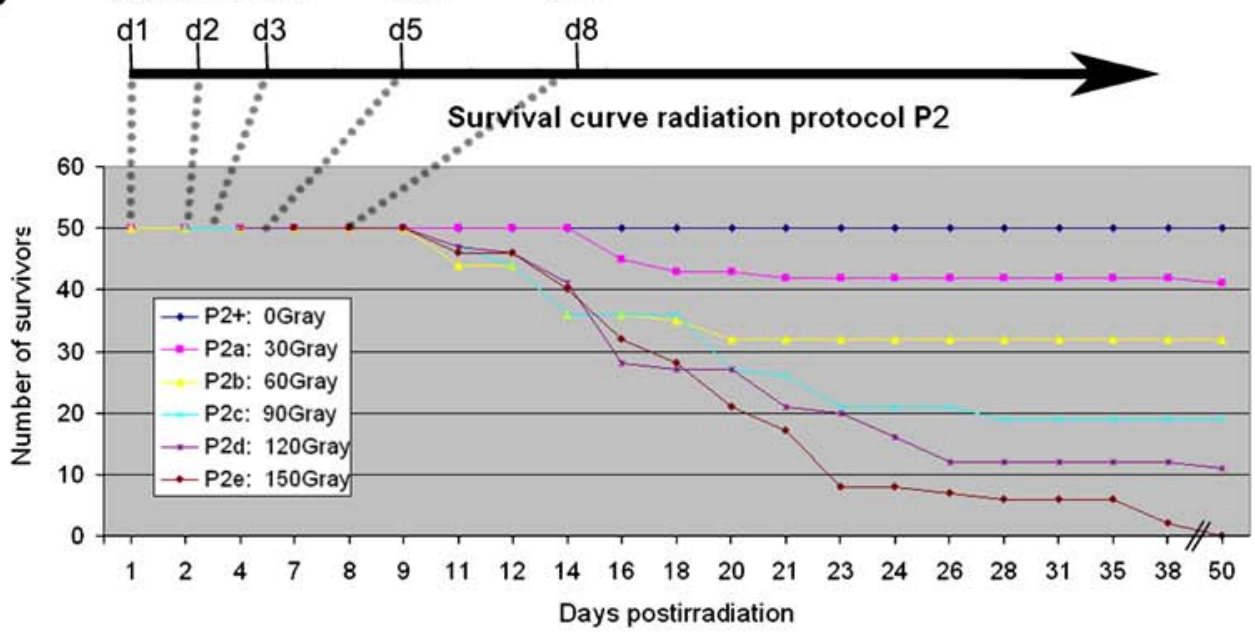

C

$\begin{array}{ll}30 G 15 G & 30 G 15 G \\ 15 G 30 G & 15 G 30 G \\ 15 G & 15 G\end{array}$

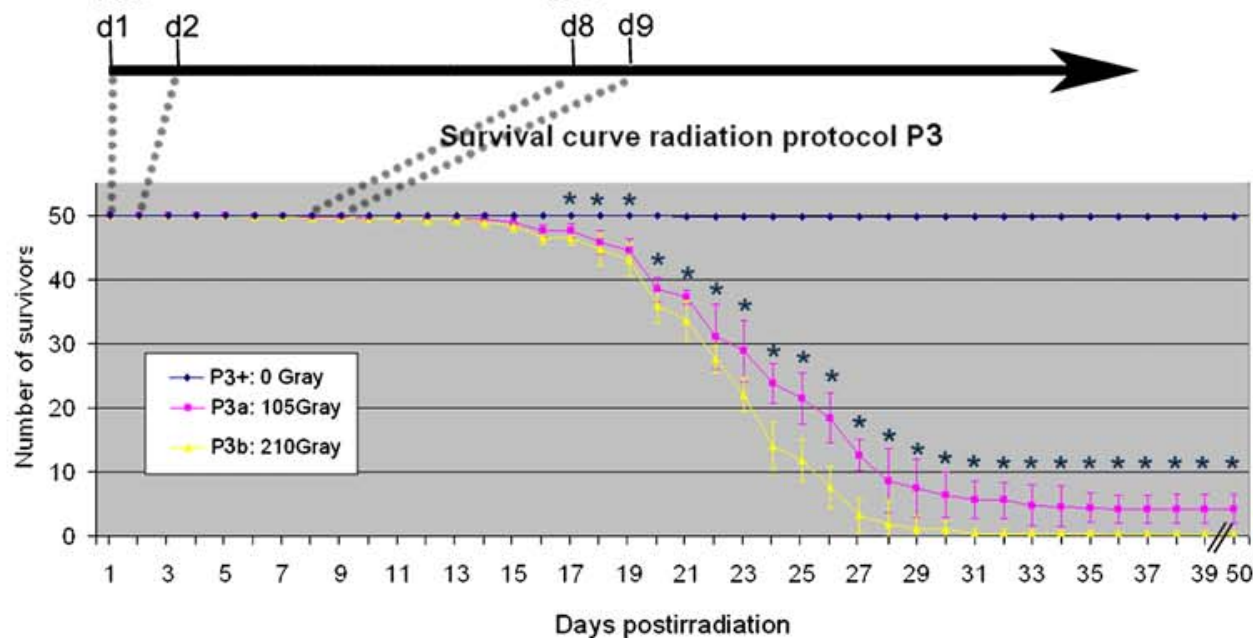


Fig. 2 Cell proliferation

$(B r d U)$, macpiwi (PIWI), macboule (BOULE) and macactin $(A C T I N)$ expression dynamics at 3 weeks following irradiation with doses of 30-90 Gy (protocol P1). Anterior is to the top (e eyes). $\mathbf{a}_{1-6}$ Somatic stem cell proliferation recovered at all radiation doses. $\mathbf{b}_{1-6}$ Macpiwi expression was completely restored in the gonads ( $t$ testes, $o$ ovaries, de developing eggs) and in the somatic stem cell population (arrowheads; $\mathbf{b}_{\mathbf{1 - 5}}$ ), except at the highest radiation dose (b) $\mathbf{c}_{\mathbf{1}-\mathbf{6}}$ Macboule expression was reconstituted at all radiation doses. $\mathbf{d}_{\mathbf{1}-\mathbf{6}}$ Expression of the housekeeping gene macactin was identical to that in control animals. Note the smaller body size of animals irradiated with higher doses $\left(\mathbf{a}_{\mathbf{6}}, \mathbf{b}_{\mathbf{6}}, \mathbf{c}_{\mathbf{6}}, \mathbf{d}_{\mathbf{6}}\right)$. Bar $100 \mu \mathrm{m}$ (all worms)

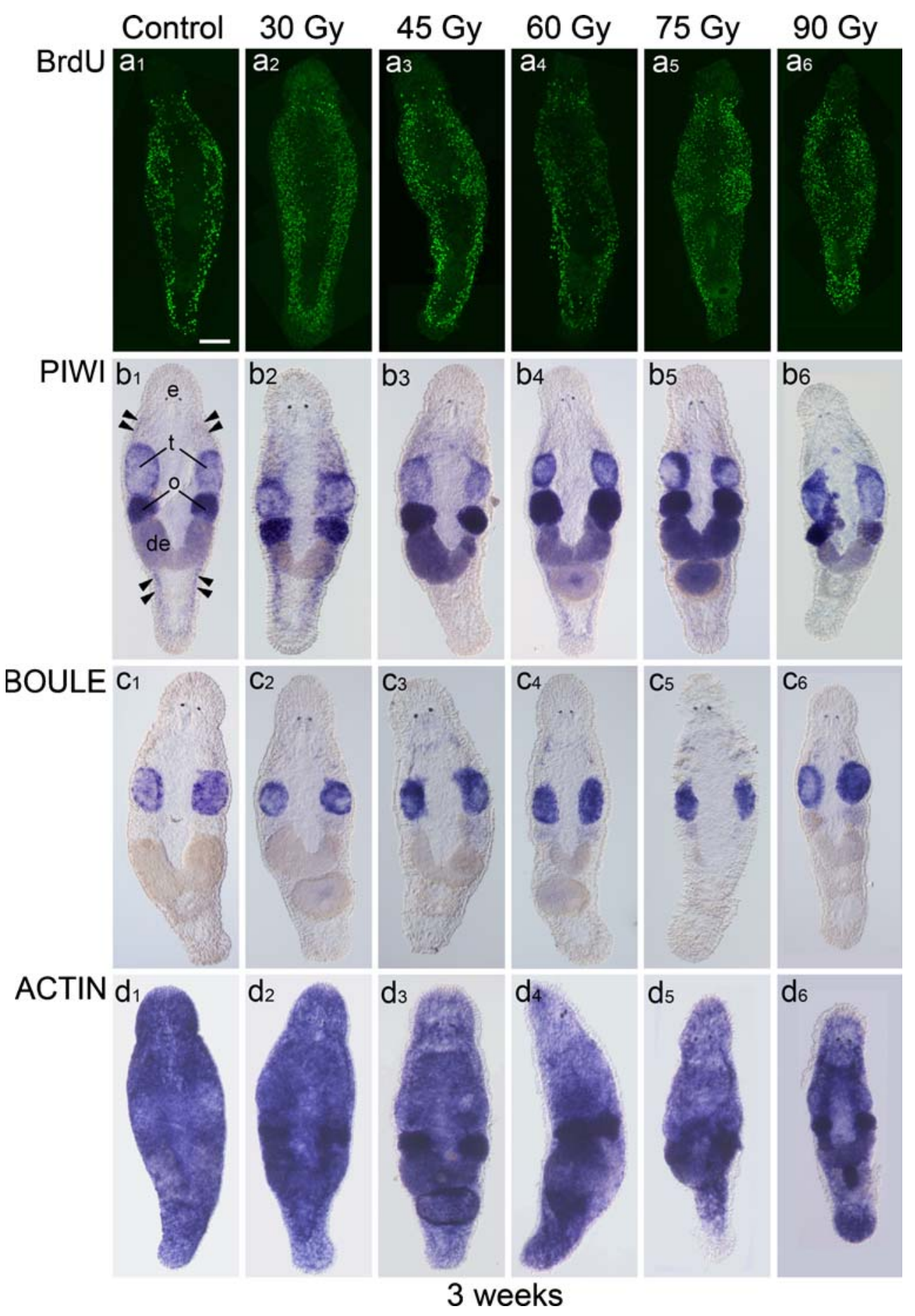

expression (Fig. $2 \mathrm{~d}_{1-6}$ ) were almost fully restored. However, because of a prolonged time period in which tissue homeostasis was delayed, irradiated animals were smaller in size than were control animals.

Second, an accumulating total dose of 120 or $150 \mathrm{~Gy}$ (protocols P2d-P2e) caused a significant reduction in cell proliferation activity until 1 week post-treatment (Fig. $3 \mathrm{a}_{1-4}$, $\left.\mathrm{S} \mathrm{A}_{1-4}\right)$ and a decrease in macpiwi, macboule and macactin expression (Fig. $3 b_{1-4}, c_{1-4}, d_{1-4}$ ). From 2 weeks following the last exposure to irradiation, animals gradually regained their cell proliferation ability (Figs. $3 \mathrm{a}_{5}, \mathrm{a}_{6}, \mathrm{~S}_{5} \mathrm{~A}_{5}, \mathrm{~A}_{6}$ ) and stem cell gene expression comparable to controls (Figs. $3 b_{5}$, $\left.\mathrm{b}_{6}, \mathrm{~d}_{5}, \mathrm{~d}_{6}, \mathrm{~S} 5 \mathrm{~B}_{5}, \mathrm{~B}_{6}, \mathrm{D}_{5}, \mathrm{D}_{6}\right)$. Again, a dose-dependent difference in recovery was observed. Specimens that were radiated with a dose of 150 Gy recovered more slowly than did worms radiated with an accumulated dose of 120 Gy.

Third, we performed a fractionated radiation protocol with a total dose of 210 Gy (protocols P3a-P3b). This time, 
Fig. 3 Cell proliferation, macpiwi, macboule and macactin expression dynamics, following fractionated irradiation for up to 3 weeks (150 Gy, protocol P2e). Anterior is to the top ( $t$ testes, de developing eggs, $o$ ovaries, arrowheads somatic stem cells, $e$ eyes). $\mathbf{a}_{1-6}$ Cell proliferation was drastically decreased for up to 1 week post-irradiation $\left(\mathbf{a}_{1-4}\right)$ but gradually recovered by up to 3 weeks post-irradiation $\left(\mathbf{a}_{5}, \mathbf{a}_{\mathbf{6}}\right)$. $\mathbf{b}_{1-6}$ Macpiwi expression was initially completely abolished $\left(\mathbf{b}_{1-3}\right)$, then slightly recovered (arrowheads in $\mathbf{b}_{\mathbf{4}}, \mathbf{b}_{\mathbf{5}}$ ) and was reconstituted after 3 weeks $\left(\mathbf{b}_{\mathbf{6}}\right)$. $\mathbf{c}_{1-6}$ Macboule expression was not detectable until the first week post-irradiation (c1-4), then recovered within the next 2 weeks $\left(\mathbf{c}_{5}, \mathbf{c}_{\mathbf{6}}\right)$. The animal in $\mathbf{c}_{6}$ was rotated under the cover slip and hence the position of the gonads appears to be central. $\mathbf{d}_{\mathbf{1 - 6}}$ Expression of macactin decreased until the second week post-irradiation $\left(\mathbf{d}_{\mathbf{4}}, \mathbf{d}_{\mathbf{5}}\right)$, but increased again to control expression levels after 3 weeks $\left(\mathbf{d}_{\mathbf{6}}\right)$. Bar $100 \mu \mathrm{m}$ (all worms)

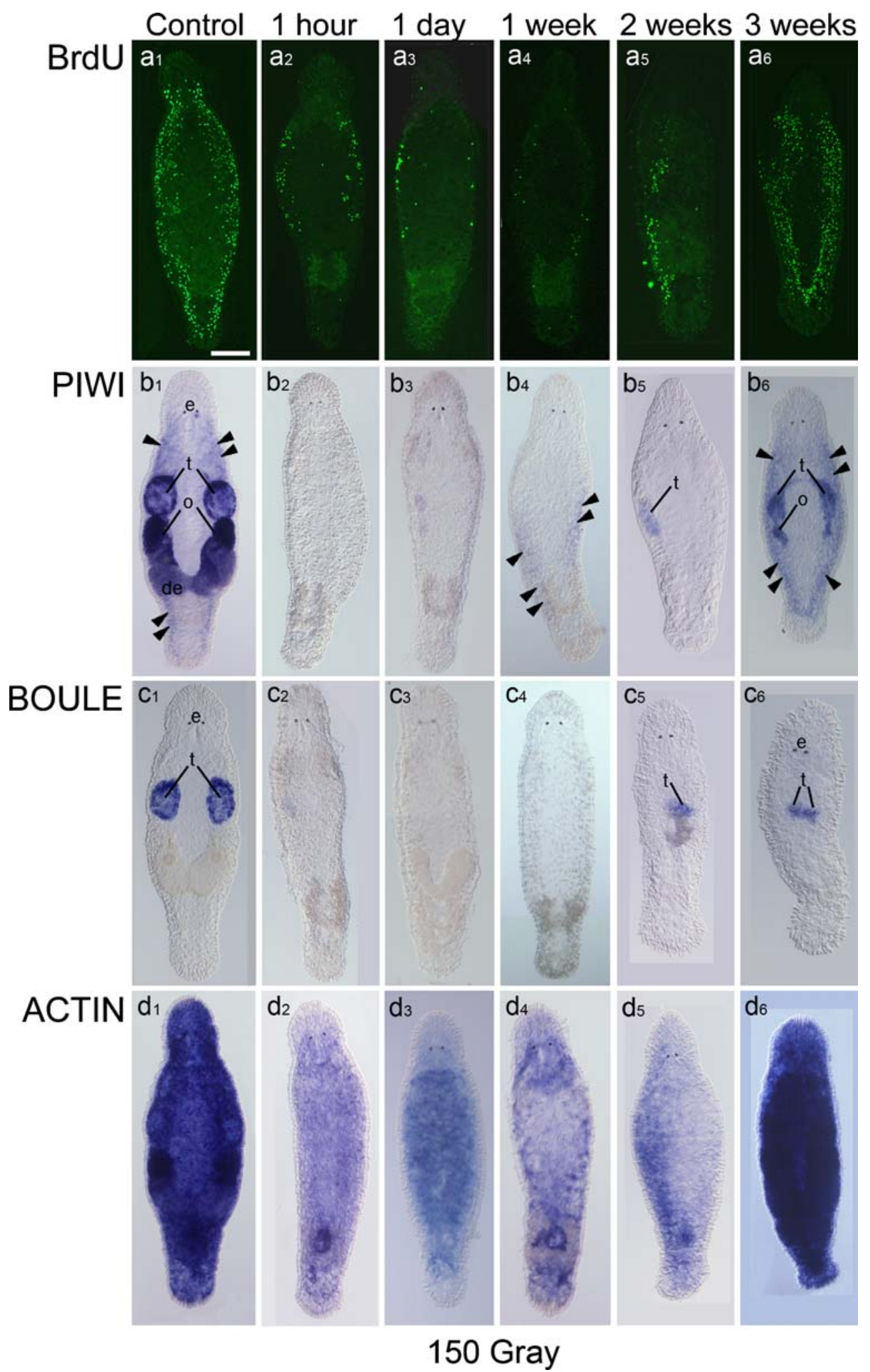

few BrdU incorporation was detected for up to 23 days after the first dose administration (Fig. $4 \mathrm{a}_{1-5}$ ). In addition, macpiwi (Fig. $4 \mathrm{~b}_{1-5}$ ) and macboule expression (Fig. $4 \mathrm{c}_{1-5}$ ) remained completely abrogated. Macactin expression gradually re- duced over time, because of a loss of tissue homeostasis (Fig. $4 \mathrm{~d}_{1-5}$ ). This irradiation protocol resulted in a complete lack of homeostasis and finally caused tissue disintegration and the subsequent death of all animals $(n=5 \times 50$; Fig. 1 c). 
Fig. 4 Lasting absence of cell proliferation $\left(\mathbf{a}_{1-5}\right)$, macpiwi

$\left(\mathbf{b}_{1-5}\right)$ and macboule $\left(\mathbf{c}_{1-5}\right)$ expression and gradual loss of macactin $\left(\mathbf{d}_{\mathbf{1 - 5}}\right)$ following a lethal fractionated dose of 210 Gy (protocol P3b). Anterior is to the top ( $t$ testes, de developing eggs, $o$ ovaries, black arrowheads somatic stem cells, white arrowheads remnant

somatic stem cells, $e$ eyes). Bar $100 \mu \mathrm{m}$ (all worms)

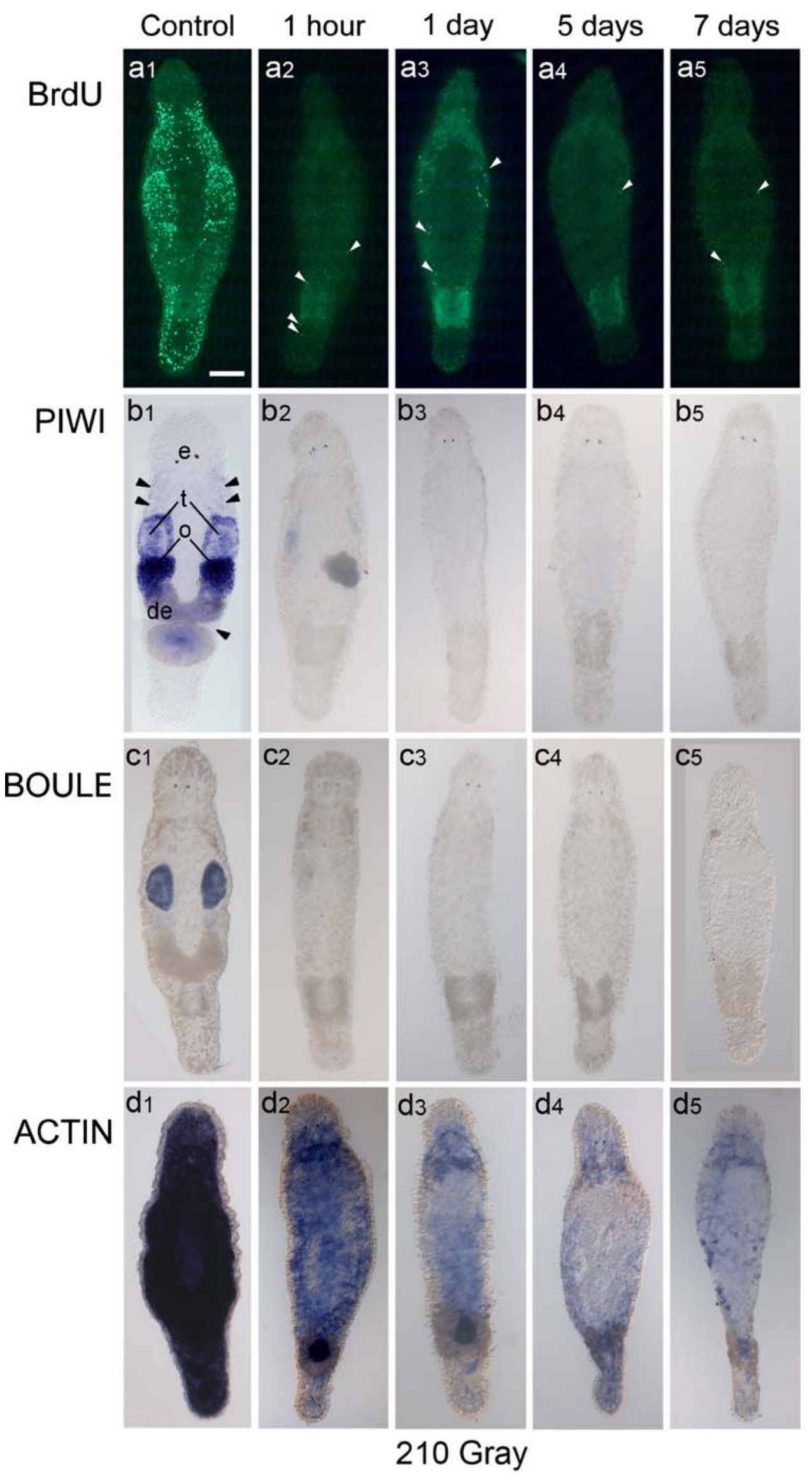




\section{Effects of radiation on morphology}

Worms that were irradiated with sublethal doses initially showed early morphological defects, confirming the downregulation of tissue turnover. However, as the stem cell system gradually repopulated, animals resumed tissue homeostasis and recovered within 6 weeks (data not shown). In contrast, fractionated irradiation with a total of 210 Gy (protocol P3b) prompted irreversible elimination of the stem cell system and, therefore, cell turnover and tissue homeostasis was not preserved. Up to 10 days post-irradiation, worms did not show aberrant morphology and looked similar to control animals (Fig. 5a), showing that exposed differentiated cells could still execute their function. From the second week on, animals started to exhibit morphological deformation with gradually increasing severity. The observed malformations were strongly reminiscent of phenotypes that became apparent following RNA interference in stem-cell-specific genes in M. lignano (De Mulder et al. 2009; D. Pfister et al., unpublished) and in the triclad Schmidtea mediterranea (Reddien et al. 2005). Therefore, we have used the corresponding terms and describe them as lesions, lysis, regression, behavioural abnormalities, blisters, bumps and curling. In addition, terminology specific to M. lignano, such as lucid tissue, eye spots modified, testis abnormal, ovary abnormal and seminal vesicle empty, have been introduced. Examples of animal phenotypes monitored after subsequent time points post-irradiation are depicted in Fig. 5.

\section{Effect of irradiation on regeneration capacity}

Exposure of M. lignano to $\gamma$-rays caused a drastic effect on the process of regeneration. Control animals formed a regeneration blastema (Fig. 6a-c'), had rebuilt their stylet after five days (Fig. 6d, d') and completely regenerated within 14 days (for details, see Egger et al. 2006).

Worms irradiated with a sublethal dose of $60 \mathrm{~Gy}$ (protocol P2b) showed a significant delay in regeneration. They still lacked a blastema at 2 days of regeneration (Fig. 6e-f') but started to form a regeneration blastema after 4 days postamputation (Fig. 6g, g'). Animals were able to regenerate the missing posterior part completely within 3 weeks (Fig. 6h, h'). Furthermore, these regenerates produced viable offspring at 6 weeks post-amputation, confirming the complete regeneration and recovery of these animals. Regenerates irradiated with a lethal accumulated dose of 210 Gy (protocol P3b) showed no sign of blastema formation (Fig. 6i-1'). Lightmicroscopic investigations demonstrated that $\gamma$-ray irradiation did not interfere with wound closure (Fig. 6i, i'), the first event of the regeneration process in which stem cells are not required (Egger et al. 2006). However, these animals were unable to proceed further in the process of regeneration (Fig. 6j-1'). Homeostasis and cell renewal were completely interrupted and animals disintegrated within the next few days.

\section{Effect of irradiation on postembryonic development}

Juvenile flatworms are known to possess fewer neoblasts in absolute numbers but exhibit a higher stem cell density and elevated metabolic rates compared with adults (Lange 1968; Hyman 1919). In M. lignano, earlier experiments with the stem cell marker piwi provided the first evidence that stem cells might be differentially regulated during development and homeostasis (De Mulder et al. 2009). To examine whether juvenile stem cells were differentially affected by radiation, we irradiated hatchlings with $60 \mathrm{~Gy}$ (P1c) and 210 Gy (P3b) and analysed the effect of $\gamma$-ray irradiation on development (Fig. 7).
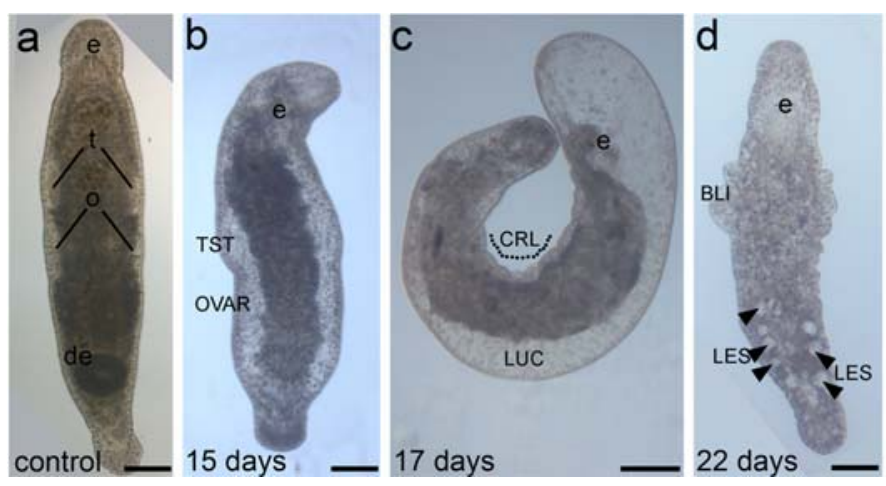

Fig. 5 Effect of lethal radiation exposure (210 Gy, Protocol 3b) on morphology. In all images, anterior is to the top. a Morphology of a control animal ( $e$ eyes, de developing egg, $t$ testes, $o$ ovaries). b, c From the second week, animals started to acquire an abnormal morphology. During this time, the gut detached from the surrounding tissue and lesions $(L U C)$ filled with liquid became detectable. b, e Note the abnormal morphology of testes and ovaries (TST, OVAR). c Several worms showed a continuous curling movement $(C R L)$. d, h During
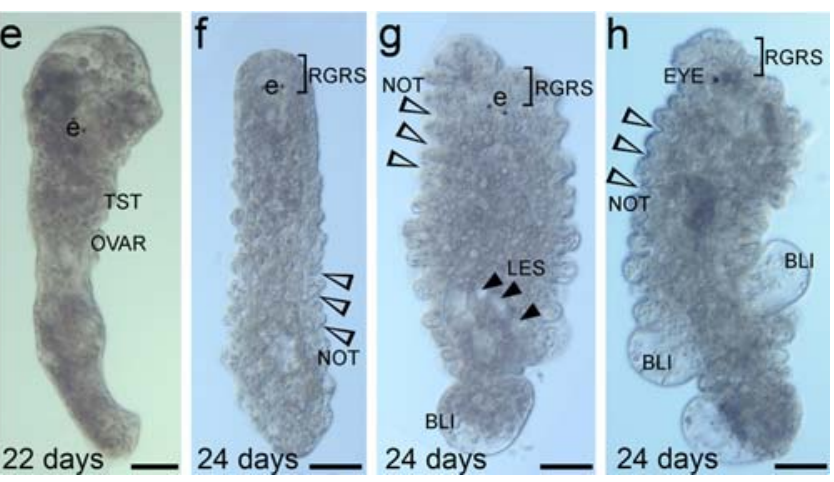

week 3, the epidermis became notched (NOT, open arrowheads), and blisters $(B L I)$ accumulated along the lateral sides. Lesions (LES) covered the entire body (black arrowheads). f-h Subsequently, the rostrum regressed $(R G R S)$. Finally, animals showed eye abnormalities $(E Y E)$, completely disintegrated and died within 1 month. When animals died, they completely disintegrated within 1 day and tissue remnants could not be observed. Bars $100 \mu \mathrm{m}$ 


\section{CONTROL}
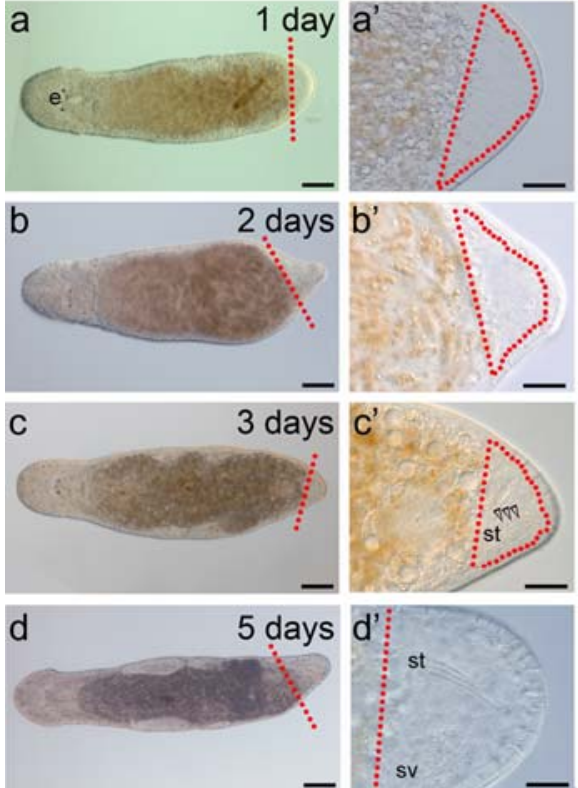
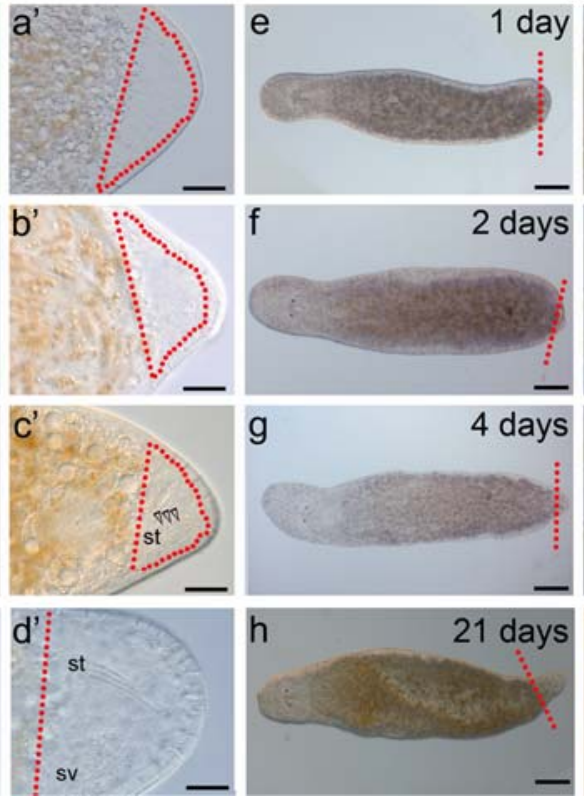

60 Gray
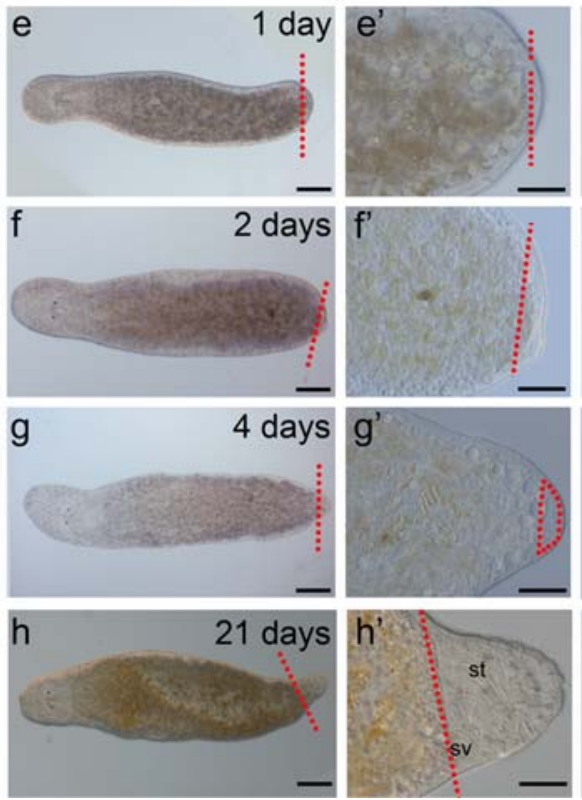

210 Gray
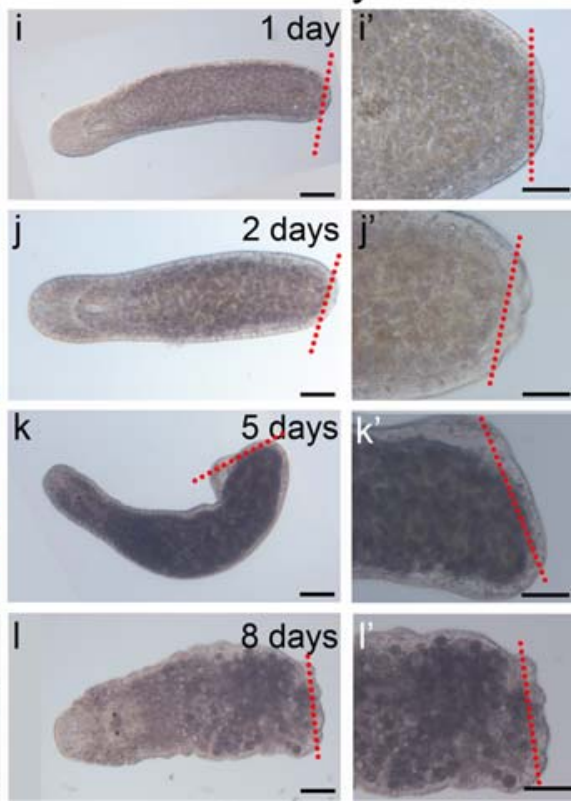

Fig. 6 Effect of irradiation on the regeneration process (red dotted lines level of amputation, red dotted circles regeneration blastema). In all images, anterior is to the left. a-d' Non-irradiated regenerates clearly formed a regeneration blastema after 1-2 days (a-b'). c, c' A forming stylet (st, open arrowheads) could be observed within the 3-day-old blastema. d, d' After 5 days, the stylet $(s t)$ and seminal vesicle $(s v)$ were rebuilt. e-g' In irradiated regenerates exposed to a sublethal dose of $60 \mathrm{~Gy}$, blastema formation was delayed. h, h' Despite this delay, the lost body part was rebuilt within 21 days, when a full stylet and a seminal vesicle were observed. i-l' In regenerates exposed to a lethal dose of $210 \mathrm{~Gy}$, no regeneration blastema could be detected. I, l' By 1 week after being cut, animals gradually started to disintegrate. Bars $100 \mu \mathrm{m}$ (a-l), $40 \mu \mathrm{m}\left(\mathbf{a}^{\prime}-\mathbf{l}\right.$ ')
Surprisingly, when hatchlings were exposed to $60 \mathrm{~Gy}$ (protocol P1c), proliferation of somatic stem cells was only slightly reduced after $1 \mathrm{~h}$ as compared with non-radiated hatchlings (Fig. $7 \mathrm{a}_{1}-\mathrm{b}_{2}$ ). This observation was in strong contrast to the effect of radiation in adult worms, which showed a significant reduction in cell proliferation (compare Fig. 7 with Electronic Supplementary Material, Fig. S1 $\mathrm{A}_{4}$ ). As early as 1 day post-irradiation, no significant difference in the distribution of proliferating cells could be observed between irradiated and control juveniles (Fig. $7 c_{1}-d_{2}$ ). Accordingly, somatic development proceeded without apparent delay (Fig. $7 \mathrm{e}_{1}-\mathrm{h}_{2}$ ). In contrast to somatic tissues, gonad development was significantly slowed in irradiated juveniles (Fig. $7 \mathrm{~g}_{1}-\mathrm{h}_{2}$ and data not shown). Whereas control juveniles start to lay eggs after 18 days of postembryonic development, irradiated hatchlings were able to produce viable eggs only after 4 weeks of development.

A second batch of hatchlings was exposed to $210 \mathrm{~Gy}$ (protocol P3b). Like adults, these hatchlings were unable to recover and finally died within 3 weeks (Fig. 7i-1).

Recovered somatic stem cells remain within lateral compartments

During the recovery period, we regularly observed that stem cells were not evenly repopulated along the lateral sides of the animals but rather in a spatially and temporally restricted pattern (Fig. 8). Cell proliferation and gene expression were often found to be restored independently on the left (Fig. 8c, f) or right side (Fig. 8d) of the animals. Moreover, we also observed that stem cell recovery occurred at either the anterior or the posterior region of the animal, at one lateral side only (Fig. 8c-e) or on both sides (Fig. 8a, e). Gonadal cells exhibited a high radio-tolerance and therefore BrdUlabelled cells were always located in this region at any time post-radiation. As a result, we were unable to distinguish somatic BrdU-labelled stem cells from gonadal BrdU-labelled cells. For this reason, we excluded this area from further considerations on somatic stem cell recovery.

Irradiation with sublethal doses permitted recovery of cell proliferation (Fig. 8) and gene expression (see Electronic Supplementary Material, Fig. S6) in one compartment (Fig. 8d, f; see Electronic Supplementary Material, Fig. S6A') or in a combination of several compartments (Fig. 8b, c, e; see Electronic Supplementary Material, Fig. S6B'-D').

In addition, BrdU pulse-chase experiments further indicated that labelled cells did not migrate to the opposite lateral side of the animal (Fig. 9). In these experiments, animals were BrdU-pulse-labelled for $30 \mathrm{~min}$ at 1 week 


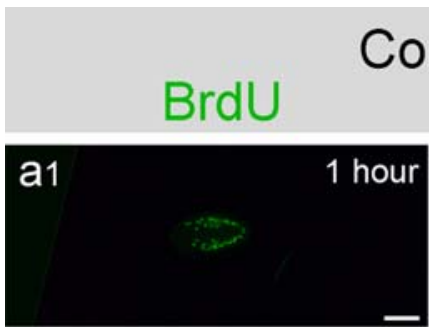

\section{Control}
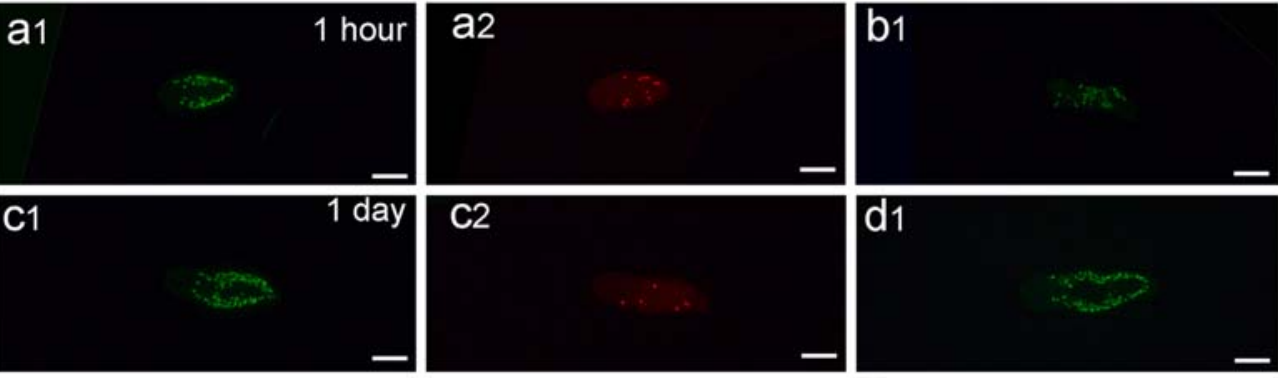

60 Gray
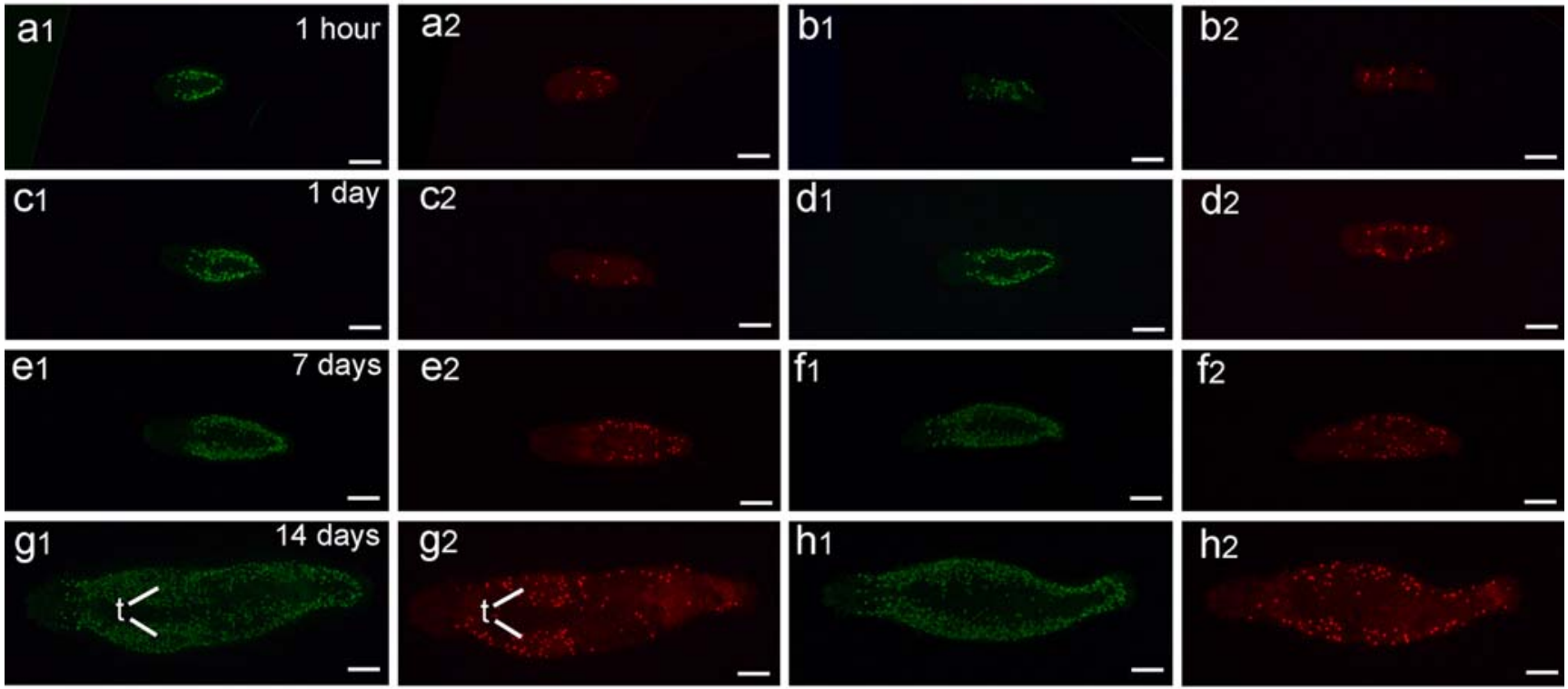

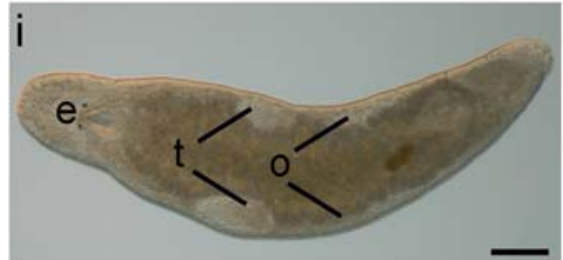

Control

Fig. 7 Radiation of hatchlings with 60 Gy $\left(\mathbf{a}_{\mathbf{1}}-\mathbf{h}_{\mathbf{2}}\right)$ or $210 \mathrm{~Gy}(\mathbf{i}-\mathbf{l})$. Note the recovery of the proliferating somatic stem cell population at $1 \mathrm{~h}\left(\mathbf{a}_{\mathbf{1}}-\mathbf{b}_{\mathbf{2}}\right), 1$ day $\left(\mathbf{c}_{\mathbf{1}}-\mathbf{d}_{\mathbf{2}}\right), 7$ days, $\left(\mathbf{e}_{\mathbf{1}}-\mathbf{f}_{\mathbf{2}}\right)$ and 14 days $\left(\mathbf{g}_{\mathbf{1}}-\mathbf{h}_{\mathbf{2}}\right)$ postirradiation (green BrdU labelling for S-phase cells, red anti-Phos-H3 staining for mitoses). At 14 days, control animals possessed testes ( $t$ in $\mathbf{g}_{1}, \mathbf{g}_{2}$ ), whereas irradiated worms had not yet developed gonads, although they had normal body length $\left(\mathbf{h}_{1}, \mathbf{h}_{2}\right)$. i-l Morphological

post-irradiation. Next, the fate of the cells that incorporated BrdU was monitored after a 3-day chase period. After recovery, BrdU-labelled differentiated cell progeny stayed within the respective compartment. Labelled cells migrated towards the midline and into the region anterior to the eyes (Fig. 9a-d). Animals with recovered stem cells in all regions exhibited a homogeneous distribution of S-phase progeny for cell renewal (Fig. 9a, a'). In animals in which stem cell recovery was spatially restricted, BrdU labelled progeny was limited to the respective compartment within the animal (Fig. 9b-d'). Notably, in all cases, BrdU-labelled cells did not cross the midline. In animals that lacked somatic stem cell recovery, only BrdU-labelled gonadal stem cells remained in testes and ovaries after the 3-day chase period (Fig. 9e-f').
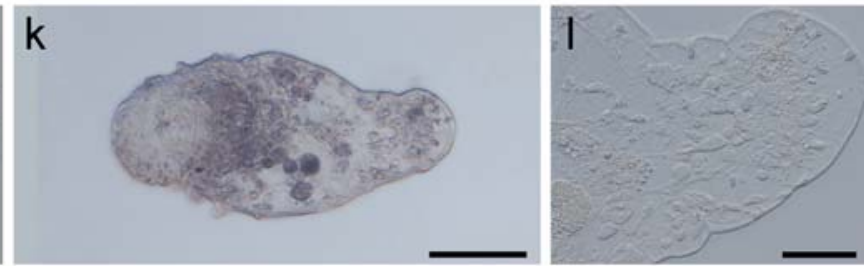

\section{Gray}

effect of lethal 210 Gy radiation on hatchlings; 18-day-old control animals $(\mathbf{i}, \mathbf{j})$ developed testes $(t)$, ovaries $(o)$, stylet $(s t)$ and a seminal vesicle filled with sperm $(s v)$, whereas irradiated hatchlings $(\mathbf{k}, \mathbf{l})$ showed tissue disorganization. Note the absence of developing testes and ovaries. I Detail of the tail plate lacking a seminal vesicle or stylet. Bars $100 \mu \mathrm{m}\left(\mathbf{a}_{\mathbf{1}}-\mathbf{h}_{\mathbf{2}}, \mathbf{i}, \mathbf{k}\right), 40 \mu \mathrm{m}(\mathbf{j}, \mathbf{l})$

\section{Discussion}

Effect of various fractionated irradiation protocols on survival rate

Previous experiments have revealed that stem cells in $M$. lignano cannot be eliminated by using a single irradiation dose of up to 200 Gy (Pfister et al. 2007; M. Mahlknecht and P. Ladurner, unpublished). The current study demonstrates that, instead, treatment with fractionated radiation exposure is required. Quiescent neoblasts, which are known to be present in M. lignano (Bode et al. 2006), might be activated upon radiation and have to be eliminated by additional exposures in order irreversibly to knock down the complete stem cell system. This situation is in contrast 
Fig. 8 Stem cell recovery in lateral compartments. a Representation indicating the recovery of somatic stem cells ( $e$ eye, mo mouth opening, green dots BrdU-labelled cells, anterior ovals testes, posterior ovals ovaries, red brackets region in which stem cell recovery was followed). b-f Schematic drawings of the recovery of cell proliferation (BrdU). b'-f' Expression of macpiwi. $\mathbf{b}, \mathbf{b}$ ' Recovery occurred in all regions. c-f' Recovery of proliferating cells in different regions of the animal. Bars $100 \mu \mathrm{m}$
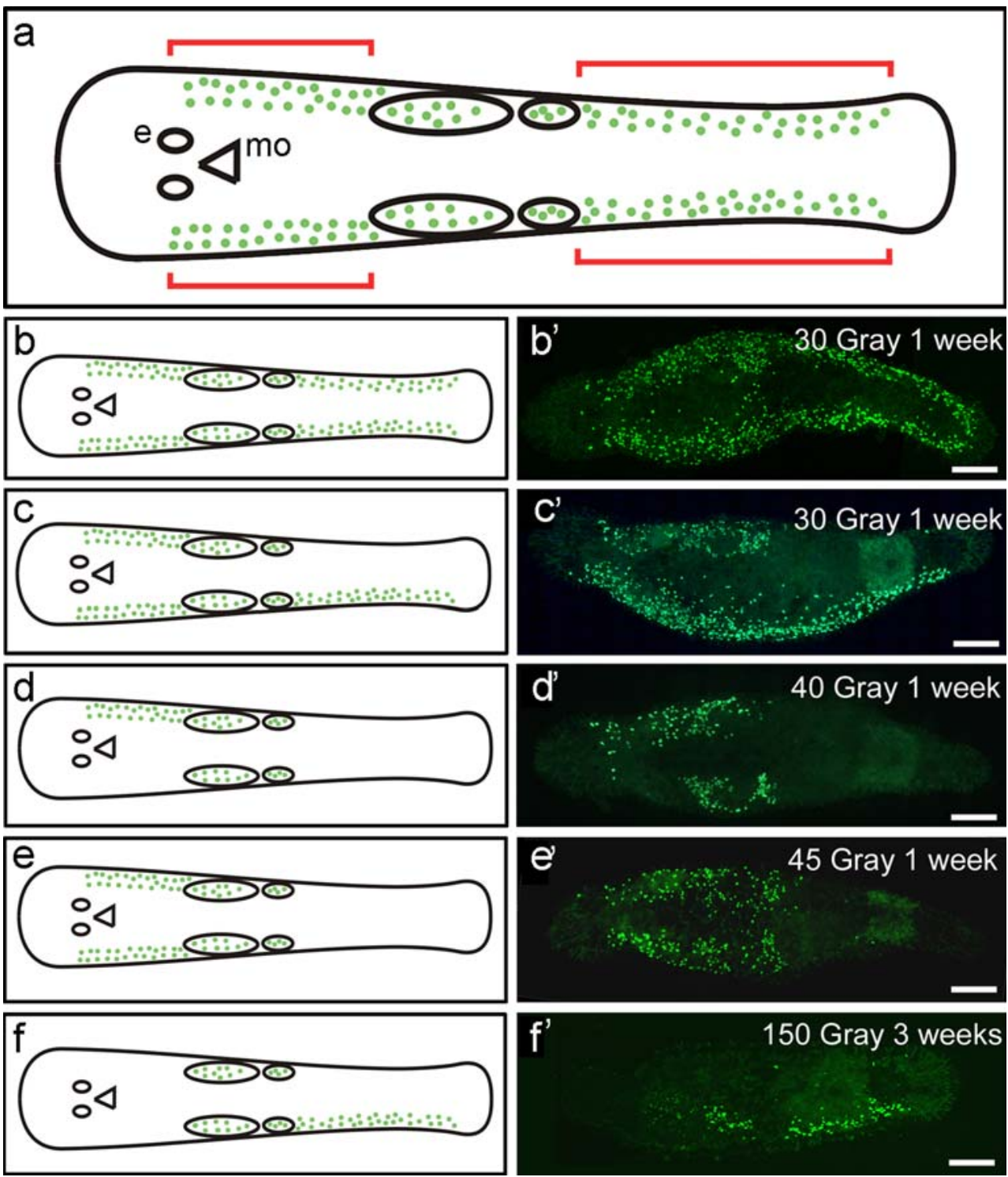

to that of triclads, in which quiescent neoblasts apparently do not persist (Newmark and Sanchez 2000) and single $\gamma$ ray exposure causes the complete and immediate elimination of the stem cell system.

Analysis of the survival curves of various fractionated radiation protocols in $M$. lignano have revealed a common pattern: (1) survival is inversely proportional to the delivered radiation dose, (2) no matter which irradiation dose is applied, survival is nearly $100 \%$ during the first 10 days followed by a sharp drop during the third week post-irradiation, (3) most individuals that survive the first 3 weeks post-irradiation recover completely, as shown by the stabilization of the survival curve, (4) surviving animals regain their normal morphology, behaviour and reproduction within 6 weeks.

A comparable situation has been observed in triclads (Kobayashi et al. 2008) and can be explained by the finding that post-irradiation mortality depends on two factors: (1) the degree of depletion of intact stem cells and (2) the rate of depopulation of essential differentiated cells (cell turnover; Lange 1968). As no visible phenotype is present during the first 10 days postirradiation, somatic tissues are presumably not directly damaged, the death of the animals probably being caused by loss of tissue renewal resulting from the elimination of stem cells. From earlier BrdU pulse chase experiments, we know that the different cell types have different turnover rates (Ladurner et al. 2000). Whereas one third of the epidermis is renewed within 2 weeks, nerve cells have a significantly slower turnover rate of up to several months (M. Hrouda and X. Verdoodt, personal communication). In addition to in situ hybridization for piwi, actin and boule, we also performed SFRP (secreted frizzled-related protein) in situ hybridization, which labels neuronal cells 
Fig. 9 Fate of BrdU-labelled cells after 3-day chase in sublethally irradiated animals. In all images, anterior is to the left ( $e$ eyes, mo mouth opening). a, a' Animal with recovered stem cells in all regions showing a homogeneous distribution of BrdU-labelled cells. Note that differentiated BrdU-labelled cells migrated towards the midline and into the rostrum (region anterior to the eyes. b-d' Partial recovery of cell proliferation. e-f' Lack of somatic stem cell recovery; BrdU labelled cells are present only within the gonads. Bars $100 \mu \mathrm{m}$
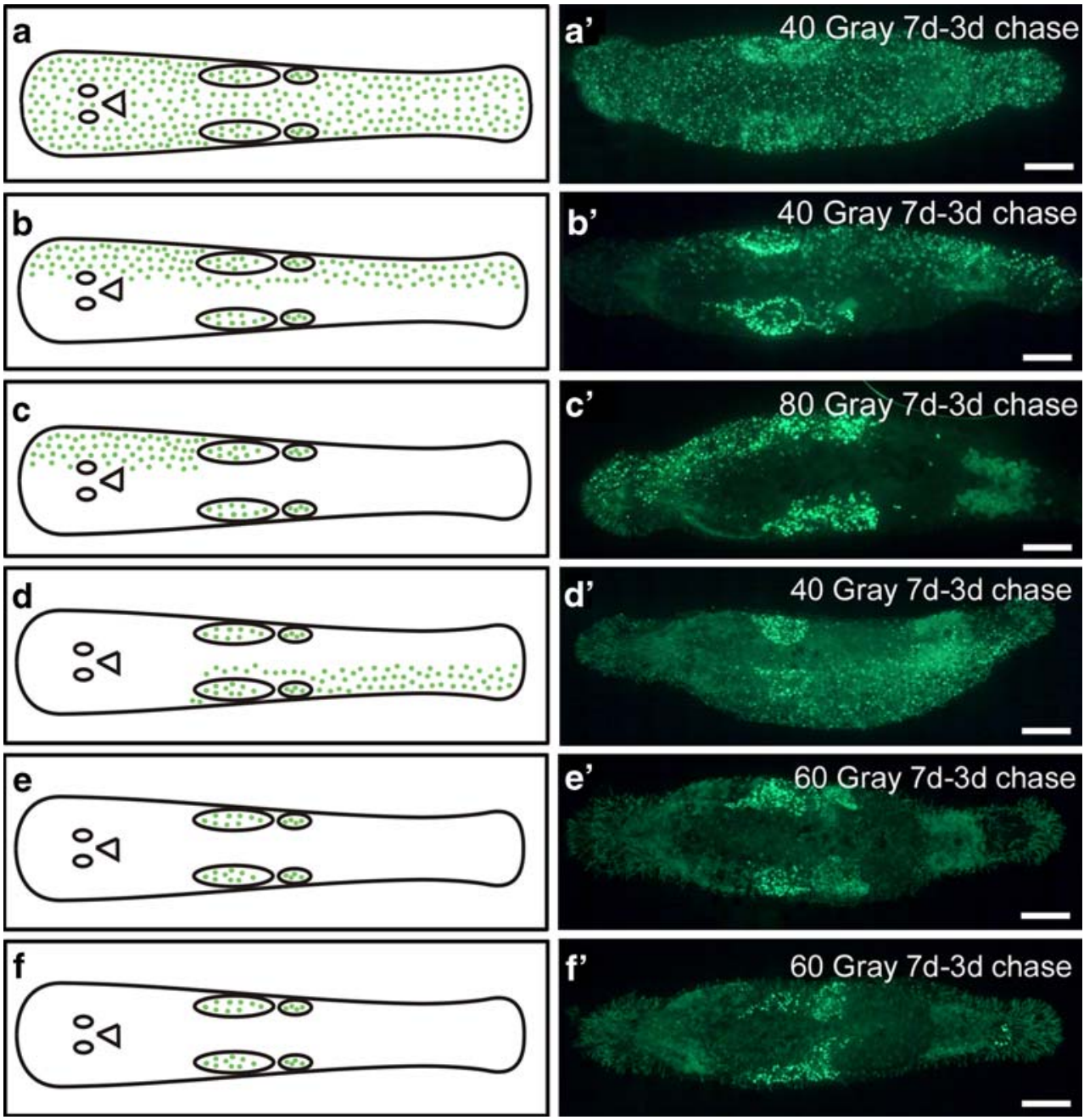

in M. lignano. SFRP gene expression is unaffected up to 2 weeks after irradiation. This demonstrates a significantly slower turnover rate of these cells compared with that of epidermal cells (data not shown). Taking these results together, we conclude that the morphological phenotype from 10 days onwards and the lethality after 3 weeks is attributable to a lack of the renewal of critical tissues.

Basis of radiation resistance and recovery capacity in M. lignano

The high radiation resistance of $M$. lignano is probably not an adaptation to daily outdoor radiation. The normal average outdoor dose of absorbed radiation is estimated to be less than $5 \times 10^{-3}$ Gy/year (Grasty and LaMarre 2004), which is far too low to be considered as the selective force that builds the observed degree of radio-resistance. The biological basis for stem cell recovery in M. lignano upon irradiation might have various reasons, of which the most plausible hypotheses are summarized below.
First, somatic stem cells might be able to re-enter the cell cycle and repopulate the stem cell population. Preliminary experiments with a BrdU pulse directly before irradiation indicate such a possibility (data not shown). Moreover, in triclads, a subpopulation of radio-resistant cells has recently been suggested to re-acquire their proliferation capabilities and to repopulate the triclad body after sublethal $\gamma$-ray treatment (Salvetti et al. 2009).

Second, since quiescent neoblasts are known to exist in M. lignano (Bode et al. 2006), these stem cells are probably activated upon irradiation and gradually repopulate the stem cell pool. During the cell cycle, periods of high radiosensitivity (G2 and $M$ phase) alternate with phases of increasing radio-resistance caused by the limited time for repair mechanisms or by the restricted access to repair mechanisms (G1 and late S phase; Pawlik and Keyomarsi 2004). About $25 \%$ of the neoblasts are in S-phase versus only $3 \%$ in mitosis (the radio-sensitive period) at each time point in $M$. lignano (Bode et al. 2006; Ladurner et al. 2000), which might partly explain our lack of success in eliminating the whole stem-cell system by using a single 
dose of irradiation. Interestingly, in other flatworms such as triclads, single-dose irradiation is sufficient to eliminate the stem-cell system, all at once, resulting in a lethal phenotype. This significant difference in radiation resistance might be attributable to the absence of quiescent neoblasts in triclads (Newmark and Sanchez 2000).

Third, in triclads, gonadal stem cells have been shown to cross the germline/somatic stem cell border to participate in the recovery of the somatic stem cell population (Gremigni and Miceli 1980). In addition, the transdetermination of less radio-sensitive, committed or differentiating cells has recently been suggested to play a role in triclads (Salvetti et al. 2009). Although we cannot exclude this hypothesis, hatchlings that do not yet possess gonads are able to recover from comparable radiation doses, indicating that other mechanisms might also exist. Grafting experiments, in which labelled gonadal cells are transplanted into lethally irradiated hosts, might help univocally to refute or confirm this theory. Alternatively, the survival and recovery capacity of irradiated specimens from which the gonads have been completely removed before $\gamma$-ray exposure could be examined.

Fourth, stem cells in M. lignano might possess a notable DNA repair mechanism. For some radio-resistant organisms, such as the bacterium Deinococcus radiodurans and the bdelloid rotifer Adineta vaga, radiation resistance is assumed to be an accidental coincidence of an evolutionary process that has permitted these organisms to cope with environmental stress (Gladyshev and Meselson 2008; Mattimore and Battista 1996). In these organisms, for instance, a coincidence between radiation resistance and desiccation has been proposed, since the same repair and protecting mechanisms are used, e.g. DNA repair and the expression of late embryogenesis abundant protein to protect DNA against desiccation. This hypothesis might also partially explain the difference in radiation recovery between M. lignano and triclads. M. lignano can cope with extremely harsh environmental conditions in its natural habitat. The occurrence of $M$. lignano on beaches that are covered with seawater only during extreme high-tide events has several consequences. Animals are exposed to high temperatures, elevated salinity and abrupt freshwater conditions during rain phases alternating with frequent dry periods. In contrast, freshwater triclads occur on the underside of rocks and stones that are constantly submerged. This triclad environment might not have prompted evolutionary adaptations indirectly leading to increased resistance to environmental DNA damage and/or radiation. Therefore, we suggest that $M$. lignano has evolved cellular and molecular adaptations to manage variable environmental conditions. In particular, desiccation-related protection mechanisms might play a role in the increased radiotolerance of M. lignano.
Effect of radiation on postembryonic development and regeneration

In the present study, we have examined the radio-sensitivity of immature worms. Notably, when hatchlings are exposed to sublethal doses (60 Gy, Protocol P1c), they recover significantly more quickly than adults. As early as 1 day postirradiation, no significant difference in the S-phase cell distribution can be detected between irradiated and control hatchlings. This observation again contrasts with the situation in triclads in which Lange (1968) has observed no significant differences in the sensitivity to radiation between young, immature and adult specimens; the author assumes that the neoblast density (which decreases with age) and the absolute number of neoblasts (which increases with age) are the two main factors determining the radiation-induced mortality in planarians. We currently have no indication of whether the differential radio-tolerance between juvenile and adult $M$. lignano is based on the density, number, identity or plasticity of neoblasts. Senescence, for instance, might (in)directly affect the stem cell system. Adult stem cells might be affected more severely or are able to recover only more slowly following radiation. Alternatively, as we have previously found, based on the functional analysis of the stem cell marker macpiwi, stem cells during development might be differentially regulated (De Mulder et al. 2009). Finally, stage-1 stem cells, which are only found during development and regeneration but absent in adult animals, might be more radio-tolerant (Bode et al. 2006).

Neoblasts are generally considered to be the source for regeneration in flatworms. This study shows that worms irradiated with a sublethal dose of $60 \mathrm{~Gy}$ are able to regenerate, although with a significant delay in the regeneration process. A similar effect has recently been described in the triclad Dugesia japonica in which sublethally irradiated worms experience a delay in regeneration (Salvetti et al. 2009). We have not tested the regeneration capacity of all sublethal doses. Exposure of $M$. lignano to a fractionated irradiation dose of $210 \mathrm{~Gy}$, on the other hand, results in the complete failure of blastema formation. Radiated Dugesia ryukyuensis fail to regenerate but completely lyse within 16 days post-irradiation, at doses as low as 2.2-8.8 Gy (Kobayashi et al. 2008). These results further confirm that stem cells are crucial for regeneration in $M$. lignano, since the complete elimination of the stem cell population by irradiation causes a complete loss of regeneration capacity.

Recovery of the stem cell system and tissue homeostasis seem to be restricted to distinctive compartments

At $1 \mathrm{~h}$ after irradiation, the number of S-phase cells is drastically reduced in all irradiation protocols; our obser- 
vations imply that this is caused either (1) by an immediate stall in S-phase progression or (2) by rapid elimination of lethally damaged neoblasts. During sublethal dose exposure, some neoblasts evidently escape irreversible injury and are thus able to repopulate the stem cell system. Following sublethal doses, only individual BrdU-positive cells are present from $1 \mathrm{~h}$ to up to 1 week post-irradiation and are distributed along the lateral sides of the flatworms. However, at 2 and 3 weeks post-irradiation, significant recovery is apparent. When animals are irradiated with lower doses of up to $40 \mathrm{~Gy}$, the stem cell system and gene expression are completely reconstituted. The data presented here provide the first evidence that the recovery of the stem cell system takes place in a spatially restricted manner. In addition, our experiments indicate that recovered stem cells remain restricted to their compartment; they do not seem to migrate far along the anterior-posterior axis and do not cross the midline. This hypothesis is further supported by the finding that flatworms maintain a clear midline during homeostasis. Several cues such as homologues of slit and bone morphogenetic protein might inhibit the migration of neoblasts over the midline (Cebria et al. 2007; Molina et al. 2007; Reddien et al. 2007). In earlier experiments, unilaterally radiated triclads have been shown to be able to form a lateral regeneration blastema (Dubois 1949). However, whether neoblasts migrate over the midline during lateral regeneration or start to migrate before the midline has been repositioned in the non-irradiated body half remains to be elucidated. In addition, more work has to be performed to determine whether the anterior-posterior compartments have a biological effect.

\section{Concluding remarks}

Our findings thus contribute to a better understanding of the stem cell system of M. lignano. They should further help to elucidate the way in which stem cell systems are organized in flatworms and other organisms.

Acknowledgments We thank two anonymous reviewers for their useful comments. We are grateful to Martina Hrouda for the SFRP clone.

Open Access This article is distributed under the terms of the Creative Commons Attribution Noncommercial License which permits any noncommercial use, distribution, and reproduction in any medium, provided the original author(s) and source are credited.

\section{References}

Agata K (2003) Regeneration and gene regulation in planarians. Curr Opin Genet Dev 13:492-496

Andersen RA, Berges RA, Harrison PJ, Watanabe MM (2005) Appendix A-recipes for freshwater and seawater media; enriched natural seawater media. In: Anderson RA (ed) Algal culturing techniques. Elsevier Academic, Amsterdam, p 507

Baguna J, Salo E, Auladell C (1989) Regeneration and pattern-formation in planarians. 3. Evidence that neoblasts are totipotent stem-cells and the source of blastema cells. Development 107:77-86

Bode A, Salvenmoser W, Nimeth K, Mahlknecht M, Adamski Z, Rieger RM, Peter R, Ladurner P (2006) Immunogold-labelled Sphase neoblasts, total neoblast number, their distribution, and evidence for arrested neoblasts in Macrostomum lignano (Platyhelminthes, Rhabditophora). Cell Tissue Res 325:577-587

Bosch TC (2008) Stem cells: from Hydra to man. Springer, Berlin Heidelberg New York

Brondsted HV (1969) Planarian regeneration. Pergamon, Oxford

Cebria F, Kobayashi C, Umesono Y, Nakazawa M, Mineta K, Ikeo K, Gojobori T, Itoh M, Taira M, Sanchez AA, Agata K (2002) FGFR-related gene nou-darake restricts brain tissues to the head region of planarians. Nature 419:620-624

Cebria F, Guo T, Jopek J, Newmark PA (2007) Regeneration and maintenance of the planarian midline is regulated by a slit orthologue. Dev Biol 307:394-406

De Mulder K, Pfister D, Kuales G, Egger B, Salvenmoser W, Willems M, Steger J, Fauster K, Micura R, Borgonie G, Ladurner P (2009) Stem cells are differentially regulated during development, regeneration and homeostasis in flatworms. Dev Biol 334:198-212

Dubois F (1949) Contribution a l'étude de la migration des cellules de regeneration chez les Planaires dulcicoles. Bull Biol Fr Belg 83:213-283

Egger B, Ladurner P, Nimeth K, Gschwentner R, Rieger R (2006) The regeneration capacity of the flatworm Macrostomum lignanoon repeated regeneration, rejuvenation, and the minimal size needed for regeneration. Dev Genes Evol 216:565-577

Egger B, Gschwentner R, Rieger R (2007) Free-living flatworms under the knife: past and present. Dev Genes Evol 217:89-104

Eisenhoffer GT, Kang H, Sanchez AA (2008) Molecular analysis of stem cells and their descendants during cell turnover and regeneration in the planarian Schmidtea mediterranea. Cell Stem Cell 3:327-339

Gladyshev E, Meselson M (2008) Extreme resistance of bdelloid rotifers to ionizing radiation. Proc Natl Acad Sci USA 105:5139-5144

Grasty RL, LaMarre JR (2004) The annual effective dose from natural sources of ionising radiation in Canada. Radiat Prot Dosimetry 108:215-226

Gremigni V, Miceli C (1980) Cytophotometric evidence for cell "transdifferentiation" in planarian regeneration. Wilhem Roux's Arch 188:107-113

Guo T, Peters AH, Newmark PA (2006) A Bruno-like gene is required for stem cell maintenance in planarians. Dev Cell 11:159-169

Handberg-Thorsager M, Fernandez E, Salo E (2008) Stem cells and regeneration in planarians. Front Biosci 13:6374-6394

Hyman LH (1919) The invertebrates: Platyhelminthes and Rhynchocoela. McGraw-Hill, New York

Kobayashi K, Hashiguchi T, Ichikawa T, Ishino Y, Hoshi M, Matsumoto M (2008) Neoblast-enriched fraction rescues eye formation in eye-defective planarian "menashi" Dugesia ryukyuensis. Dev Growth Differ 50:689-696

Ladurner P, Rieger R, Baguna J (2000) Spatial distribution and differentiation potential of stem cells in hatchlings and adults in the marine platyhelminth Macrostomum sp.: a bromodeoxyuridine analysis. Dev Biol 226:231-241

Ladurner P, Scharer L, Salvenmoser W, Rieger R (2005) A new model organism among the lower Bilateria and the use of digital microscopy in taxonomy of meiobenthic Platyhelminthes: Macrostomum lignano, n. sp. (Rhabditophora, Macrostomorpha). J Zool Syst Evol Res 43:114-126

Ladurner P, Egger B, De Mulder K, Pfister D, Kuales G, Salvenmoser W, Scharer L (2008) The stem cell system of the basal flatworm Macrostomum lignano. In: Bosch TC (ed) Stem cells: from Hydra to man. Springer, pp 75-94 
Lange CS (1968) Studies on the cellular basis of radiation lethality. I. The pattern of mortality in the whole-body irradiated planarian (Tricladida, Paludicola). Int J Radiat Biol Relat Stud Phys Chem Med 13:511-530

Mattimore V, Battista JR (1996) Radioresistance of Deinococcus radiodurans: functions necessary to survive ionizing radiation are also necessary to survive prolonged desiccation. J Bacteriol 178:633-637

Molina MD, Salo E, Cebria F (2007) The BMP pathway is essential for re-specification and maintenance of the dorsoventral axis in regenerating and intact planarians. Dev Biol 311:79-94

Morrison SJ, Spradling AC (2008) Stem cells and niches: mechanisms that promote stem cell maintenance throughout life. Cell 132:598-611

Newmark PA, Sanchez AA (2000) Bromodeoxyuridine specifically labels the regenerative stem cells of planarians. Dev Biol 220:142-153

Newmark PA, Sanchez AA (2002) Not your father's planarian: a classic model enters the era of functional genomics. Nat Rev Genet 3:210-219

Nimeth K, Ladurner P, Gschwentner R, Salvenmoser W, Rieger R (2002) Cell renewal and apoptosis in Macrostomum sp [Lignano]. Cell Biol Int 26:801-815

Nimeth KT, Mahlknecht M, Mezzanato A, Peter R, Rieger R, Ladurner P (2004) Stem cell dynamics during growth, feeding, and starvation in the basal flatworm Macrostomum sp. (Platyhelminthes). Dev Dyn 230:91-99

Nimeth KT, Egger B, Rieger R, Salvenmoser W, Peter R, Gschwentner $\mathrm{R}$ (2007) Regeneration in Macrostomum lignano (Platyhelminthes): cellular dynamics in the neoblast stem cell system. Cell Tissue Res 327:637-646

Orii H, Kato K, Umesono Y, Agata K, Watanabe K (1999) The planarian HOM/HOX homeobox gene (plox) expressed along anterior-posterior axis. Dev Biol 210:73-87

Orii H, Sakurai T, Watanabe K (2005) Distribution of the stem cells (neoblasts) in the planarian Dugesia japonica. Dev Genes Evol 215:143-157

Palakodeti D, Smielewska M, Lu YC, Yeo GW, Graveley BR (2008) The PIWI proteins SMEDWI-2 and SMEDWI-3 are required for stem cell function and piRNA expression in planarians. RNA 14:1174-1186

Pawlik TM, Keyomarsi K (2004) Role of cell cycle in mediating sensitivity to radiotherapy. Int J Radiat Oncol Biol Phys 59:928-942

Pfister D, De Mulder K, Philipp I, Kuales G, Hrouda M, Eichberger P, Borgonie G, Hartenstein V, Ladurner P (2007) The exceptional stem cell system of Macrostomum lignano: screening for gene expression and studying cell proliferation by hydroxyurea treatment and irradiation. Front Zool 4:9
Pfister D, De Mulder K, Hartenstein V, Kuales G, Borgonie G, Marx F, Morris J, Ladurner P (2008) Flatworm stem cells and the germ line: developmental and evolutionary implications of macvasa expression in Macrostomum lignano. Dev Biol 319:146-159

Reddien PW, Sanchez AA (2004) Fundamentals of planarian regeneration. Annu Rev Cell Dev Biol 20:725-757

Reddien PW, Oviedo NJ, Jennings JR, Jenkin JC, Sanchez AA (2005) SMEDWI-2 is a PIWI-like protein that regulates planarian stem cells. Science 310:1327-1330

Reddien PW, Bermange AL, Kicza AM, Sanchez AA (2007) BMP signaling regulates the dorsal planarian midline and is needed for asymmetric regeneration. Development 134:4043-4051

Rieger R, Gehlen M, Hazpruhnar G, Homlund M, Legnitit A, Salvenmoser W, Tyler S (1988) Laboratory cultures of marine Macrostomida (Turbellaria). Fortschr Zool 36:525

Rossi L, Salvetti A, Lena A, Batistoni R, Deri P, Pugliesi C, Loreti E, Gremigni V (2006) DjPiwi-1, a member of the PAZ-Piwi gene family, defines a subpopulation of planarian stem cells. Dev Genes Evol 216:335-346

Rossi L, Salvetti A, Marincola FM, Lena A, Deri P, Mannini L, Batistoni R, Wang E, Gremigni V (2007) Deciphering the molecular machinery of stem cells: a look at the neoblast gene expression profile. Genome Biol 8:R62

Rossi L, Salvetti A, Batistoni R, Deri P, Gremigni V (2008) Planarians, a tale of stem cells. Cell Mol Life Sci 65:16-23

Salvetti A, Lena A, Rossi L, Deri P, Cecchettini A, Batistoni R, Gremigni V (2002) Characterization of DeY1, a novel Y-box gene specifically expressed in differentiating male germ cells of planarians. Gene Expr Patterns 2:195-200

Salvetti A, Rossi L, Lena A, Batistoni R, Deri P, Rainaldi G, Locci MT, Evangelista M, Gremigni V (2005) DjPum, a homologue of Drosophila Pumilio, is essential to planarian stem cell maintenance. Development 132:1863-1874

Salvetti A, Rossi L, Bonuccelli L, Lena A, Pugliesi C, Rainaldi G, Evangelista M, Gremigni V (2009) Adult stem cell plasticity: neoblast repopulation in non-lethally irradiated planarians. Dev Biol 328:305-314

Sanchez AA (2004) Regeneration and the need for simpler model organisms. Philos Trans R Soc Lond Biol 359:759-763

Tanaka EM (2003) Cell differentiation and cell fate during urodele tail and limb regeneration. Curr Opin Genet Dev 13:497-501

Tsai RY, Kittappa R, McKay RD (2002) Plasticity, niches, and the use of stem cells. Dev Cell 2:707-712

Weissman IL (2000) Stem cells: unit of development, units of regeneration and units in evolution. Cell 100:157-168

Wollf E, Dubois F (1948) Sur la migration des cellules de regeneration chez les planaires. Rev Suisse Zool 55:218-227 